\title{
Medicinal folk remedies of vegetables
}

\author{
Misbah Manzoor*, Mufakhirah durrani, Rukhsana Jabeen, Shazia Irfan, Ayesha Luqman, Sidra Bibi \\ *Department of Plant Sciences, Sardar Bahadur Khan Women's University, Quetta, Pakistan \\ Department of Biology Alama Iqbal open unviversity, Islamabad. \\ Department of Plant Sciences SBK Women's University Quetta,Balochistan., Department of Plant Sciences SBK Women's University \\ Quetta,Balochistan., Department of Plant Sciences SBK Women's University Quetta,Balochistan.,SBK Women's University \\ Quetta,Balochistan \\ *Corresponding author_E-mail: Alfa_botany@yahoo.com
}

\begin{abstract}
Vegetables are the source of medication for preventive, curative, protective or primitive purposes. In this study, the use of medicinal vegetables and their role to treat different diseases has been observed. In this study twenty-six vegetables belonging to 12 families; were investigated for various disorders. They were used for their preventive and curative properties. These vegetables, apart from their roles as food additives and supplements, they may also be utilized as an effective and cheap source of antibacterial, antiviral, antifungal. Anti-protozoa, ant-inflammatory, antidiabetic and antitumourgenic agents for the treatment of various infections.

These vegetables include cruciferous vegetables, Trigonellafoenum-graecum, Abelmoschusesculentus, Solanummelongena, Momordicacharantia, Lycopersiconesculentum, Allium cepa, Momordica tuberose, Zingiberofficinale, Spinasiaoleraceae.

Daucuscarota and Allium sativum are the most important vegetables; while Cucurbitapepo, Colocasiaesculenta, Ipomoea batatas, Beta vulgaris, Phaseolus vulgaris, Brassica rapaRaphanussativus, Brassica oleraceae, Cucumissativus, Cucumismelo, Cucumiscallosus, Ocimumgratissimum, Telfairiaoccidentalis and Solanumtuberosum also play an important role in the treatment of different types of diseases. The study recorded that Allium sativum, Spinasiaoleraceae and Daucuscarota, are the most relevant vegetables used in the treatment of various diseases while Cucumismelo, Ocimumgratissimum, and Telfairiaoccidentalis are less relevant vegetables.

It was revealed that an intake of about 280 grams of vegetables per day per person is considered essential for maintenance of good health. Of this, leafy vegetables should constitute 40 percent, roots and tubers 30 percent and the other vegetables like brinjals, lady finger the remaining 30 percent.
\end{abstract}

Keywords: Medicinal plants, Vegetables, Ethnobotanical study.

\section{Introduction}

About 6,000 flowering plants have been reported to occur in Pakistan. In Pakistan more than 200 plantspecies are reported by Anderson (1988), which are used to treat a variety of diseases including cough, kidney stone, stomach problems, malaria, hepatitis, urinary disorders, toothache, inflammation, skin problems and pneumonia, (Hayat, M.Q. et al .2008). Plants are the source of medication for preventive, curative, protective or primitive purposes. Their use for digestive disorders can be commonly observed at household level. (Sidhu, K. et al .2007).In addition to the major food constituents'proteins, fat and carbohydrate and micronutrients such as vitamins, minerals and trace elements, they contain other compounds that may have a positive effect on human health. These photochemical include groups of glucosinolates, allylic-sulphides, isothiocyanates, dietary fibers, phytosterolsand monoterpenes. (Bergquist,S. 2006).

Several studies have been shown that vegetables provide a good source of vitamins and minerals. They possess seven times more calcium, twice the iron, and one hundred and ninety times more $\beta$-carotene and seventy eight times more vitamin c. (Mathieu,G. et al.2007).There are increasing evidence that the consumption of fruit and vegetables and in takeof certain nutrients that are present in foods reduce the risk of various pathological events such as cancer and cardioand cerebro-vascular diseases.(SEMIZ ,A. And A. SEN .2009).

A number of compounds present in Vegetablesoils have been proven effective in a treating a wide range of conditions ranging from irritable bowl syndrome to chronic liver disease. Similarly many of the fatty acids and other compounds 
present in. Vegetablesoils have long been known to benefit our health. (Ather ,M. And S.M. Nasir. 2005). Recently, most effects to prevent and treat neurodegenerative disorders focus on dietary antioxidant components, including vitamins and phenol compounds. Anthocyaninsare a class of naturally Polyphenolic compounds that give the intense color to many flowers and fruits in the high plants. They have been reported to show several effective pharmacological properties such as anti-inflammation, antioxidant and anti mutagen (Shan,Q. et al.2009).

Functional food products are aimed at introducing human dietary ingredients that aid specifically bodily functions in addition to being nutritious. The Anthocyanins are the predominant group of visible Polyphenols and comprise the red, purple and blue pigmentation of many plants. They represent a diverse group of secondary metabolites including important natural antioxidants and food colorants. Anthocyaninshave some positive therapic effects such as in the treatment of diabetic retinopathy and fibrocystic disease of the breast and vision disorders. Anthocyaninsmay also have other potential physiological effects as an antineoplasticagents, radiation protective agents, vasotonicagents, vasoprotective and anti-inflammatory agents, chemoprotective agents against platinum toxicity in anti-cancer therapy, Hepatoprotective agents against carbon tetra chloride effects due to their interaction with various enzymes and metabolic processes. (Islam ,S. 2006).Phenolic compounds exist universally in most of the vegetables, which are also rich sources of natural antioxidants. Dietary antioxidants have attracted special attention because they can protect the human body from oxidative stress, which may cause many disease including cancer, ageing and cardiovascular diseases.

\section{OBJECTIVES}

- To make aware the local people about the medicinal value of vegetables

- To determine the pharmaceutical and nutritive value of vegetables

- To determine the beneficial nutrients of vegetables

\section{Review of literature}

For the first 5000 years of civilization, humans relied on food and herbs for medicines. Only in the past 50 years have we forgotten our medicinal "roots" in favor of patent medicines. This study investigated the results past/present research on vegetables carried out by different scientists and presented to the local population to encourage them for their medicinal uses to treat different diseases.

Afzal,M. et al. (2000) worked on the medicinal potential of garlic and reported that garlic is used as an effective remedy for a variety of chronic ailments including cardiovascular conditions, hyperlipidemia, diabetes, cancer and infectious disease and also has anti tumourigenic, antibacterial, antigangrene and antiatherosclerosis activities.

Liu,S. et al. (2000) reportedthat higher intake of fruits and vegetables may be protective against cardiovascular diseases, particularly for women. The study revealed that greater fruit and vegetable intake was associated with a higher prevalence of diabetes, hypertension and high cholesterol. These recommendations are primarily based on the belief that fruit and vegetables intake may reduce CVD risk through the beneficial combination of micronutrients, antioxidants, phytochemicals and fiber in these foods.

Keiss,H.P.et al.(2003) workedon the immuno-modulatory and anti-inflammatory properties of garlic (Allium sativum). They investigated that garlic powder extracts (GPE) and single garlic metabolites modulate lipopolysaccharide (LPS) induced cytokinelevels in human whole blood. They demonstrated the treatment of a diversity of disorders by garlic inducing heatdisease, headache, tumors and it serves as antithrombotic, lipid lowering, anti tumoural, antioxidant, nuclear factor and as an important player in the regulation of the immune system.

Panagiotakos,D.B.et al.(2003) investigated the association between coronary heart disease risk and the consumption of fruit and vegetables in a large number of cardiac patients and controls. The study evaluated that the antioxidant, potassium, fiber and folate content of fruits and vegetables could at least partially explain their protective effect CHD and other compounds such as flavonoids, phytates, lycopene, carotenoids and other phytochemicals in vegetables may also have significant protective effects in reducing coronary risk. It was concluded that the consumption of vegetables more than 3 days/week was associated with $70 \%$ lower risk for $\mathrm{CHD}$ and a $10 \%$ reduction in coronary risk was observed for every one piece of fruit consumed per day.

Dangi,R.S. (2004) describedthe important medical and culinary aspect of Trigonellafoenum-graecumwhich was commonly grown as a vegetable. The study demonstrated that genetic variation present between Trigonellacaerulea and Trigonella-foenum-graecum. It was concluded that this plant was an anti-diabetic herb which can lower blood glucose and cholesterol levels.

Kala,C.P.et al. (2005) studied the medicinal plants used by traditional vaidyasin uttaranchalstate of India.Documented 456 medicinal plantsspecies during the surveys of these $55 \%$ were cultivated and $45 \%$ werewild species, $80 \%$ of the cultivated species were found to be growing in the kitchen gardens and $20 \%$ in the agricultural fields. Among these medicinal plants, some vegetables are also involved in the treatment of different diseases such as Allium cepa(payaz), Allium sativum(lahsun), Brassica rapa(shaljam), Brassicarugosa(rai), Coriandrumsativum (dhania),Daucuscarota 
(gajar), Lycopersiconesculentum(tamatar), Menthalongifolia (pudina),Momordicacharantia(karela)and Trigonellafoenum-graecum (methi) are used in stomachache, high blood pressure, diabetes, improving eyesight and blood purification.

Ghyur.M.N. and A.H. Gillani (2005) studied the pharmacological activities of ginger exhibit anti-inflammatory, antipyretic, antimicrobial, hypoglycemic, antimigraine,antischistosomal, antioxidant, hepatoprotective, diuretic, hypocholesterolemicandantihypertensiveactivities. They conducted that Ginger has been traditionally used in disorders of the gastrointestinal tract, as a stomachache, laxative, sialogogue, gastric emptying enhancer, appetizer, Antiemetic, antidyspepticand at the same time, as an antidiarrealand anticolicagent.

Stefani,E.D. et al. (2005) reported the role of vegetable and fruit consumption in the etiology of squamous cell the carcinoma of the oesophagusin the case-control study in Uruguay. It was investigated that high total vegetables and fruit consumption wasthe strongest protective food group for this malignancy. The vegetables included as a raw vegetables(carrot, tomato, potato, Sweet potato, beetroot, winter squash, cabbage, cauliflower, zucchini and red pepper). When raw and cooked vegetables were analyzed during the study, the cooked vegetables were found more significantly and inversely associated with risk of squamous cell cancer of oesophagusand in fruits, citrus fruit is strongly protective against squamous cell carcinoma of oesophagus.

Rashidkhani.B. et al.(2005) studied the relationship between fruit and vegetable consumption and renal cell carcinoma. It was emphasized that the consumption of fruit and vegetable to prevent or slow the development of cancer include the presence in plant foods of such potentially anticarcinogenicsubstances such as carotenoids, vitamin C, vitamin E, dithiolthiones,isoflavones, and isothiocyanates. It was concluded that the risk of RCC increased monotoxicallywith increasing intake frequencies of fruit juice ( $\mathrm{P}$ value for trend=0.10) while within the group of vegetables the strongest inverse association was observed for root vegetables $(\mathrm{P}=0.03$ by Wald test). The risk of RCC decreased with increasing consumption frequencies of white cabbage ( $\mathrm{P}$ for trend 0.07 ) and frequent consumption of salad vegetables (once or more per day) decreased the risk by $40 \%$.

Doorn ,M. et al.(2006) worked on the beneficial effects of garlic on the risk factors associated with cardiovascular disease (CVD) by carrying out the epidemiologic studies and investigating the effects of a chemically wellcharacterized garlic preparation on biomarkers for inflammation, endothelial function and lipid metabolism in subjects with risk factors for CVD.

Parekh ,J. And S. Chanda (2007) reported the in vitro screening of antibacterial activity of aqueous and alcoholic extracts of various Indian species against selected pathogens from Enterobacteriaceae. They investigated thirty-four medicinal plants, belonging to twenty-eight different families, among these few vegetables of family Chenopodiaceae and Cucurbitaceae are also involved. From Chenopodiaceae Beta vulgaris and Spinacioleraceae have the medicinal properties such as aphrodiasic, carminative, diuretic, emmenagogue, expectorant, purgative, tonic and are used in the treatment of constipation, earache, headache, inflammations, itch, paralysis, sores and ulcers while MomordicacharantiaCucurbitaceae have the medicinal properties such as tonic, purgative, anthelmintic, laxative, sedative, expectorant, and stimulant and is used in the treatment of bronchitis, cough, elephantiasis, piles and ulcers.

Gueye ,M. And D. Meissa ,(2007) investigated the medicinal uses of leafy vegetables in Senegal. Forty (40) species of vegetable leaves which are traditionally consumed in Senegal have been inventoried. These species are distributed amongst 21 families, the most abundant of which are Amaranthaceae, Malvaceae, Moraceae, Fabaceae and the Tiliaceae. It was noted that the leaves and roots of Amaranth healsear infection, wounds, pustules, lepromes, abscesses and burns. The leafy vegetables are said to be tonics and will also be effective against diabetes, rickets, arterial hypertension, constipation and they are rich sources of vitamins.

Kimiywe,J. et a. $l(2007)$ worked on the medicinal value of utilization of indigenous vegetables consume in urban and peri-urban Nairobi. The most common illness cited were malaria, diarrhea, anemia, colds and coughs, skin infection, malnutrition, HIV/AIDS, diabetes and high blood pressure. Some common vegetables medicinally used such as pumpkin leaves used to treat diabetes, high blood pressure, backache and improve eyesight; Garlic is used to treat colds and coughs, high blood pressure, stomach, cancer, asthma, and TB; Ginger is used to treat colds and coughs, high blood pressure; Okra is used for stomachacheand anemia. It was concluded that the vegetables have a medicinal value attached to it and some were said to cure more than one disease.

Cavagnaro,P.E. et al .(2007) reported the contribution of Onion in its raw form to the prevention of cardiovascular diseases as an antiplaterletagent. The study evaluated the effect of different heat treatments on Onion induced antiplaterlet activity, pyruvate concentration and pungency sensory perception and to established relationships among these traits in cooked onions. It was concluded that in order to obtain the maximum health benefits onion should be crushed and eaten raw or slightly cooked. The invitro results of the study suggested that extensively cooked onions may stimulate rather than inhibit-platelet aggregation.

Ahmad, M. et al.(2007) worked on the medicinal plants including vegetables of the district Attock in the North of Punjab province of Pakistan. They reported that vegetables such as Abelmoschusesculentus (bhindi), Momordicacharantia (karela),Cucurbitapepo(kadoo), Raphanussativus (Mooli) have been used in common diseases like cough, throat infection, bronchitis, diabetes, otitis, ear ailments, digestive disorders etc. they found that 25 species belonging to 25 genera were used for common ailments among the local inhabitants of the area. 
Sidhu ,K. et al.(2007) worked on the prevention and cure of digestive disorders through the use of medicinal plants. They investigated that 28 plants were used for digestive disorders and most of them were herbs. Among these medicinal plants, some vegetables are also involved in the prevention and cure of various disorders. These include Allium cepa(payaz), Spinaciaoleraceae L. (spinach), and Allium sativum(garlic), which are used in five (5) common digestive disorders namely diarrhea and dysentery, constipation, stomach pain, vomiting and food poisoning.

Goodrich ,W.S. and Rosati (2008) worked on the composition comprising vegetable/herbal-based dietary ingredients, or extracts which contains vitamins and nontoxic treatment for liver cancer, hepatitis and liver cirrhosis and useful or effective in possibly other cancers. It was investigated that dietrycarotenoids-rich extracts from carrots, tomatoes and orange juice have been shown in rat model cellular events thought to play a role in the early stages of hepatocarcinogenesis which is a complex incremental process that usually evolves the identification of tumors. The study concluded that cruciferous vegetables including broccoli shows a reduction in chemically induced tumor formation. The study revealed that Brassicaoleraceae, Daucuscarota and Spinasiaoleraceaehave antioxidant activity and are useful against liver cancers.

Sisodia,R. et al.(2008) investigated the radio protective efficacy of Spinach against radiation induced oxidative stress, since its leaves are rich in antioxidants like carotenoids ( $\beta$-carotene, lutein, zeaxanthin) and high content of proteins, minerals, vitamin C. It was concluded that the Spinach extract pre-treatment renders protection against various biochemical changes in the micetestis to some extent if taken continuously which might be due to synergistic effect of antioxidant constituents present in the Spinach. The study also reported that Spinach improves cerebellerphysiology and motor learning in aged rats.

Shan, Q. et al. (2009) reported that purple sweet potato color has the neuroprotectiveeffect on the aging mouse brain induced by D-galactose (D-gal). It was investigated that PSPC decreased the expression level of glial fibrillary acidic protein (GFAP), induce able nitric oxide synthase (iNOS), and cyclooxygenase2(COX-2), inhibited nuclear translocation of nuclear factor-kappa B (NF-KB), increased the activity of copper/zinc super oxide dismutase $(\mathrm{Cu} / \mathrm{Zn}-$ SOD) and catalase (CAT) and reduced the content of malondialdehyde (MDA), respectively via its antioxidant and antinflammatorycapacity, due to the presence of naturally occurring Anthocyanins, which has a powerful antioxidant activity invitroand in vivo. Purple sweet potato (Ipomoea batatas) has been regarded as an abundant source of stable Anthocyanins and has been attracted extensive attentions.

Kumar ,R. et al.(2009) worked on mucilage extracted from the pods of Abelmoschusesculentusfor its suitability as a disintegrating agent. The mucilage extracted is devoid of toxicity. The study revealed that Abelmoschusesculentus mucilage powder was effective as disintegrantin low concentrations (4\%) W/W in tablet formation. The wok can further be extended for evaluation of its suitability as suspending agent, gelling agent, emulsifying agent and other similar pharmaceutical applications considering the easy and ample availability of the plant.

Emmanuel O.S. et al(2009) investigated that tomato paste was administered orally to prevent the Pb's adverse effect on the kidney mainly by preventing oxidation.

Ogbe,F.M. et al.(2009) worked on the medicinal plants of Nigeria used for female reproductive health care. The study recorded that 27 plants belonging to 20 families used in treating 16 female reproductive health problems and gynecological conditions. Among these plants, two leafy vegetables are also used to treat women reproductive health. These vegetables are Ocimumgratissimum and Telfairiaoccidentalis. Ocimumgratissimum contains alkaloids, saponins, tannins, phlobatannins, anthraquinones, steroids, terpenoids, flavonoids and cardiac glycosides while Telfairiaoccidentaliscontains micro and macro elements (e.g. $\mathrm{P}, \mathrm{Mg}, \mathrm{Fe}$, and $\mathrm{Zn}$ ), cyanide, tannins, oxalateand phytates.Ocimumgratissimumis documented for treating miscarriages due to its mode of action of flavonoidsthrough their ability to prevent platelet aggregation (thinning of blood). Telfairiaoccidentalis is used in treating anemia in pregnant women, which is identified as one of the direct causes of the high maternal mortality rates in Nigeria.

Goyal, M. and S.K. Sharma (2009) worked on the value addition prospects of arid foods of desert region of North West India. It was revealed that possessing of traditionally important arid foods into more use full and convenient product can improve livelihood security of the people residing in the desert region. During study, the therapeutic uses, prospects of their value addition and nutritional composition of arid foods have been enlisted, including some vegetables, such as Cucumis colossus (Kachri) which exert a cooling effect, improve appetite, easy bowel syndrome, and relieves stomach pain, vomiting and constipation; and the other vegetable is Cucumismelo(Kakri) also exert effect, improve appetite, and curesstomach pain, vomiting and constipation.

\section{Material method}

There are many methods to do such kind of research but the method which adopted is the extensive online and library research, in which the study is based through the midline of research papers, review articles and book reports to find out the medicinal value of vegetables. The relevant information regarding the therapeutic uses and processing potentials of vegetables was collected, enlisted and their taxonomic position determined the scientific names, common names of vegetables along with their medicinal uses are provided. Tables also summarize the ailments, main constituents of 
various vegetables and their principal method of application. During study, the past practices regarding the use of medicinal plants or vegetables were recorded and required information was used for achieving the objectives of the study. A similar kind of research can also be done by the following methods.

\section{Structural questionnaires:}

Through the administration of a structural questionnaire in oral interviews, information was also obtained from professional herbalists, faculty members, local people and knowledgeable old woman. The questionnaire contained pertinent questions relating to vegetable use for different diseases including mode of preparation, administration and their traditional knowledge.

\section{Results}

First traditional uses of vegetables were collected and Second, identified vegetables were then evaluated based on their nutritive and medicinal values.

During study, total 26 vegetables belonging to 12 families were reported. These vegetables include root vegetables, underground stem vegetables, herbage vegetables and fruit vegetables.

\begin{tabular}{|c|l|l|l|l|}
\hline S.No & Common Names & Botanical Names & \multicolumn{1}{|c|}{ Parts used } & \multicolumn{1}{c|}{ Medicinal value } \\
\hline $\mathbf{1}$ & $\begin{array}{l}\text { Beets, Beet root } \\
\text { Chukandar }\end{array}$ & $\begin{array}{l}\text { Beta vulgaris } \\
\text { Chenopodiaceae }\end{array}$ & $\begin{array}{l}\text { Roots and } \\
\text { leaves used as } \\
\text { vegetables, } \\
\text { used for sugar } \\
\text { production }\end{array}$ & $\begin{array}{l}\text { Used to treat constipation, earache, sores, } \\
\text { headache, inflammations, paralysis and ulcers[ }\end{array}$ \\
\hline $\mathbf{2}$ & Carrot, Gajar & $\begin{array}{l}\text { DaucuscarotaUm } \\
\text { belliferae }\end{array}$ & $\begin{array}{l}\text { Roots are used } \\
\text { as vegetable }\end{array}$ & $\begin{array}{l}\text { Carotene(source of vitamin A), antioxidant, } \\
\text { improving eyesight, preventcancer, blood } \\
\text { purification }\end{array}$ \\
\hline $\mathbf{3}$ & Radish, Mooli & $\begin{array}{l}\text { Raphanussativus } \\
\text { Cruciferae }\end{array}$ & $\begin{array}{l}\text { Fusiformroots } \\
\text { edible }\end{array}$ & $\begin{array}{l}\text { Leaves rich in vitamin A and C, used to treat } \\
\text { jaundice, earache and baldness. }\end{array}$ \\
\hline $\mathbf{5}$ & Swakarkand & $\begin{array}{l}\text { IpomoeabatatasC } \\
\text { onvolvulaceae }\end{array}$ & $\begin{array}{l}\text { Tuberous } \\
\text { roots edible }\end{array}$ & $\begin{array}{l}\text { Used in the manufacture of industrial alcohol, } \\
\text { syrup, glucose and starch, used to treat cancer, } \\
\text { hepatotoxicity, allergies, ageing, human } \\
\text { immunodeficiency virus and cardiovascular } \\
\text { problems. }\end{array}$ \\
\hline
\end{tabular}

Table 2: Underground stem vegetables

\begin{tabular}{|c|l|l|l|l|}
\hline S.No & $\begin{array}{l}\text { Common } \\
\text { Names }\end{array}$ & Botanical Names & Parts used & \multicolumn{1}{|c|}{ Medicinal value } \\
\hline $\mathbf{1}$ & $\begin{array}{l}\text { Garlic, } \\
\text { Lahsun }\end{array}$ & $\begin{array}{l}\text { Allium } \\
\text { sativumLiliaceae }\end{array}$ & $\begin{array}{l}\text { 'Cloves' or } \\
\text { fleshy } \\
\text { leaves used } \\
\text { as } \\
\text { condiment; }\end{array}$ & $\begin{array}{l}\text { Has antibacterial, antiviral, antifungal and } \\
\text { antiptotozoalactivity, used to treat cardiovascular } \\
\text { diseases, hyperlipaemia, diabetes, cancer and infectious } \\
\text { diseases, headache, tumors. }\end{array}$ \\
\hline $\mathbf{2}$ & $\begin{array}{l}\text { Ginger } \\
\text { Adrak }\end{array}$ & Zingiberofficinale & $\begin{array}{l}\text { Fleshy } \\
\text { leaves of } \\
\text { bulb; }\end{array}$ & $\begin{array}{l}\text { Antimicrobial, anti-inflammatory, antipyretic, } \\
\text { antihypertensive, antimigraine, hepatoprotective, } \\
\text { diuretic, hypocholesterolemic, anti-oxidative, appetizer } \\
\text { and antidiarreal }\end{array}$ \\
\hline $\mathbf{3}$ & Kachri & $\begin{array}{l}\text { CucumiscallosusCu } \\
\text { curbitaceae }\end{array}$ & $\begin{array}{l}\text { Fleshy } \\
\text { leaves of } \\
\text { bulb; }\end{array}$ & $\begin{array}{l}\text { Exert cooling effect, improve appetite, relieves stomach } \\
\text { pain, vomiting and constipation. }\end{array}$ \\
\hline $\mathbf{4}$ & $\begin{array}{l}\text { Onion, } \\
\text { Piyaz }\end{array}$ & $\begin{array}{l}\text { Allium } \\
\text { cepaLiliaceae }\end{array}$ & $\begin{array}{l}\text { Fleshy } \\
\text { leaves of }\end{array}$ & $\begin{array}{l}\text { Rich in minerals and vitamins, antiplaterletagent, treat } \\
\text { cardiovascular disease, cholera. }\end{array}$ \\
\hline
\end{tabular}




\begin{tabular}{|c|l|l|l|l|}
\hline $\mathbf{5}$ & $\begin{array}{l}\text { Potato, } \\
\text { Alu }\end{array}$ & $\begin{array}{l}\text { Solanumtuberosum } \\
\text { Solanaceae }\end{array}$ & $\begin{array}{l}\text { edible; } \\
\text { Undergrou } \\
\text { nd stem } \\
\text { tubers } \\
\text { form most } \\
\text { commonly } \\
\text { used } \\
\text { vegetable }\end{array}$ & $\begin{array}{l}\text { Helps to reduce the risk of squamous cell carcinoma of } \\
\text { the esophagus. }\end{array}$ \\
\hline $\mathbf{6}$ & $\begin{array}{l}\text { Taro, } \\
\text { Arum, } \\
\text { Arvi }\end{array}$ & $\begin{array}{l}\text { Colocasiaesculenta } \\
\text { Araceae }\end{array}$ & $\begin{array}{l}\text { Starchy } \\
\text { tuberous } \\
\text { rhizomes } \\
\text { edible. }\end{array}$ & $\begin{array}{l}\text { Treat diarrhea, irritable bowel syndrome, inflammatory } \\
\text { bowel disease, cancer, depressed immune function, } \\
\text { tuberculosis, anathematic, ulcers and pulmonary } \\
\text { congestion. }\end{array}$ \\
\hline
\end{tabular}

\begin{tabular}{|c|c|c|c|c|}
\hline \multicolumn{5}{|c|}{ Table 3: Herbage vegetables } \\
\hline S.No & $\begin{array}{l}\text { Common } \\
\text { Names } \\
\end{array}$ & Botanical Names & Parts used & Medicinal value \\
\hline 1 & $\begin{array}{l}\text { Cabbage, } \\
\text { Bandhgob } \\
\text { hi }\end{array}$ & $\begin{array}{l}\text { Brassica oleraceaeCrucifera var. } \\
\text { Capitata }\end{array}$ & $\begin{array}{l}\text { Vegetative budmade } \\
\text { of compaction of } \\
\text { leaves is edible }\end{array}$ & $\begin{array}{l}\text { Treat carcinoma of the } \\
\text { oesophagusand renal cell } \\
\text { carcinoma }\end{array}$ \\
\hline 2 & $\begin{array}{l}\text { Cauliflow } \\
\text { er, } \\
\text { phulgobhi }\end{array}$ & $\begin{array}{l}\text { Brassica oleraceae var. botrytis } \\
\text { Cruciferae }\end{array}$ & $\begin{array}{l}\text { Inflorescence of } \\
\text { consisting of } \\
\text { hypertrophied } \\
\text { flowersstalks and } \\
\text { abortive flowers eaten }\end{array}$ & $\begin{array}{l}\text { Chemoprotective, } \\
\text { antidiabetic }\end{array}$ \\
\hline 3 & $\begin{array}{l}\text { Fenugreek } \\
\text {,Methi }\end{array}$ & $\begin{array}{l}\text { Trigonellafoenum-graecum } \\
\text { Papilionaceae }\end{array}$ & Leaves eaten & $\begin{array}{l}\text { Rich in proteins, minerals } \\
\text { and vitamin C, anticancer, } \\
\text { anti-inflammatory, } \\
\text { antiseptic, aphrodisiac, } \\
\text { astringent, anthelmintic, } \\
\text { wound healing and } \\
\text { gastroprotective, useful in } \\
\text { chronic cough, cure leprosy } \\
\text { and heart disease, } \\
\text { alsoantidiabetic. }\end{array}$ \\
\hline 4 & $\begin{array}{l}\text { Leafy } \\
\text { vegetable } \\
\text { salad }\end{array}$ & OcimumgratissimumCucurbitaceae & $\begin{array}{l}\text { Rosette of leaves used } \\
\text { as salad }\end{array}$ & $\begin{array}{l}\text { Treat miscarriages and } \\
\text { prevent platelet } \\
\text { aggregation }\end{array}$ \\
\hline 5 & $\begin{array}{l}\text { Leafy } \\
\text { vegetable } \\
\text { salad }\end{array}$ & TelfairiaoccidentalisCucurbitaceae & Used as salad & $\begin{array}{l}\text { Used to treat anemia in } \\
\text { pregnant women }\end{array}$ \\
\hline 6 & Athalakkai & $\begin{array}{l}\text { Momordicatuberosa } \\
\text { Cucurbitaceae }\end{array}$ & $\begin{array}{l}\text { Used as saladbut also } \\
\text { cooked }\end{array}$ & $\begin{array}{l}\text { Decrease gastrointestinal } \\
\text { disorders, diabetes and } \\
\text { lower the cholesterol level }\end{array}$ \\
\hline 7 & $\begin{array}{l}\text { Spinach, } \\
\text { Palak }\end{array}$ & SpinasiaoleraceaeChenopodiaceae & $\begin{array}{l}\text { Compact Rosette of } \\
\text { leaves eaten }\end{array}$ & $\begin{array}{l}\text { Rich in vitamin A and } \\
\text { minerals, treat } \\
\text { cardiovascular disease, } \\
\text { cataracts, anemia, and } \\
\text { several forms of cancers } \\
\text { and has antioxidant and anti } \\
\text { proliferativeactivity. }\end{array}$ \\
\hline
\end{tabular}




\begin{tabular}{|c|c|c|c|c|}
\hline S.No & $\begin{array}{c}\text { Common } \\
\text { Names } \\
\end{array}$ & Botanical Names & Parts used & Medicinal value \\
\hline 1 & $\begin{array}{l}\text { Bitter } \\
\text { gourd, } \\
\text { Karela }\end{array}$ & $\begin{array}{l}\text { Momordicacharantia } \\
\text { Cucurbitaceae }\end{array}$ & $\begin{array}{l}\text { Fruit used as } \\
\text { vegetable }\end{array}$ & $\begin{array}{l}\text { Fruits rich in tetracyclictriterpens; useful for } \\
\text { diabetes, antioxidant, chemoprotective, treat } \\
\text { cough, bronchitis, piles and ulcers. }\end{array}$ \\
\hline 2 & $\begin{array}{l}\text { Bottle } \\
\text { gourd, } \\
\text { Lauki }\end{array}$ & $\begin{array}{l}\text { Lagenariasiceraria } \\
\text { Cucurbitaceae }\end{array}$ & $\begin{array}{l}\text { Fruits (pepo) } \\
\text { used as } \\
\text { vegetables }\end{array}$ & Fruit pulp rich in vitamin B and ascorbic acid \\
\hline 3 & $\begin{array}{l}\text { Cluster } \\
\text { bean } \\
\text { Guar }\end{array}$ & $\begin{array}{l}\text { Cyamopsistetragonolo } \\
\text { baSolanaceae }\end{array}$ & $\begin{array}{l}\text { Immature green } \\
\text { pods and seeds } \\
\text { edible; guar gum } \\
\text { from } \\
\text { endospermcomm } \\
\text { ercially useful. }\end{array}$ & Decrease the cholesterol level \\
\hline 4 & $\begin{array}{l}\text { Cucumber } \\
\text { Kheera }\end{array}$ & $\begin{array}{l}\text { CucumissativusCucurb } \\
\text { itaceae }\end{array}$ & $\begin{array}{l}\text { Fruit used as } \\
\text { vegetable }\end{array}$ & Used to treat inflammation \\
\hline 5 & $\begin{array}{l}\text { Egg plant, } \\
\text { Brinjal, } \\
\text { Baingan }\end{array}$ & $\begin{array}{l}\text { Solanummelongena } \\
\text { Solanaceae }\end{array}$ & $\begin{array}{l}\text { Fruit eaten as } \\
\text { vegetable }\end{array}$ & $\begin{array}{l}\text { Rich in iodine treat diabetes, arthritis, asthma } \\
\text { and bronchitis, degrade cholesterol. }\end{array}$ \\
\hline 6 & Kakri & $\begin{array}{l}\text { Cucumismelovar. } \\
\text { utilissimusCucurbitace } \\
\text { ae }\end{array}$ & $\begin{array}{l}\text { Fruit eaten as } \\
\text { raw vegetable }\end{array}$ & $\begin{array}{l}\text { Exert cooling effect, improve appetite, and } \\
\text { cure stomach pain, vomiting and constipation. }\end{array}$ \\
\hline 7 & $\begin{array}{l}\text { Kidney } \\
\text { bean or } \\
\text { Fraz bean, } \\
\text { Vilaitisem }\end{array}$ & $\begin{array}{l}\text { Phaseolus } \\
\text { vulgarisPapilionaceae }\end{array}$ & $\begin{array}{l}\text { Tender fruits and } \\
\text { dry ripe seeds } \\
\text { are used as } \\
\text { vegetables }\end{array}$ & $\begin{array}{l}\text { Reduce the postprandial plasma glucose levels } \\
\text { and decrease the body fat. }\end{array}$ \\
\hline 8 & $\begin{array}{l}\text { Lady's } \\
\text { finger, } \\
\text { Okra } \\
\text { Bhindi }\end{array}$ & $\begin{array}{l}\text { Abelmoschusesculentu } \\
s=\text { Hibiscus esculentus } \\
\text { Malvaceae }\end{array}$ & $\begin{array}{l}\text { Unripe fruit } \\
\text { (capsule) eaten } \\
\text { as vegetable }\end{array}$ & $\begin{array}{l}\text { Serves as immunotoxins, Abortifacients and } \\
\text { antiviral agents, treat cough, throat infection } \\
\text { and bronchitis. }\end{array}$ \\
\hline 9 & $\begin{array}{l}\text { Tomato, } \\
\text { Tamatar }\end{array}$ & $\begin{array}{l}\text { Lycopersiconlycopersi } \\
\text { cum= } \\
\text { Lycopersicumesculent } \\
\text { um } \\
\text { Solanaceae }\end{array}$ & $\begin{array}{l}\text { Raw fruits eaten; } \\
\text { juice, soup, } \\
\text { ketchup, etc; } \\
\text { popularly used }\end{array}$ & $\begin{array}{l}\text { Treat illness, attaining growth, maintaining } \\
\text { bloodin good state; reduce the acidity of } \\
\text { stomachand inflammation of oesophagusand } \\
\text { stomach. }\end{array}$ \\
\hline 10 & $\begin{array}{l}\text { Pumpkin } \\
\text { kadoo }\end{array}$ & $\begin{array}{l}\text { Cucurbitapepo } \\
\text { Cucurbitaceae }\end{array}$ & $\begin{array}{l}\text { Eaten as } \\
\text { vegetable }\end{array}$ & $\begin{array}{l}\text { Treat prostatic hyperplasia in men, obesity, } \\
\text { skin problems, irritable bladder in children, } \\
\text { intestinal disorders and gastric problems. }\end{array}$ \\
\hline
\end{tabular}

\section{Discussion}

In this study, data on 26 medicinal vegetables belonging to 12 families were presented. The main emphasis was on the traditional plant based remedies and active chemical constituents, which are, used throughout by the local people. In developing countries like Pakistan, the benefit of modern medicine and health care is a luxury because only a small percentage age of the population has access to it (Ahmad M. etal2007). The medicinal uses of vegetables have been entitled.

\section{Cruciferous Vegetables:}

Cruciferous vegetables contain high levels of dithiolthiones and isothiocyanates, which have been shown to increase the activity of enzymes involved in the detoxification of carcinogens. Cruciferous vegetables also contain indole- 3 carbinal, which possible results in the production of estradiol, which may protectagent's estrogen-related cancers such as those of the breast, endometrium and ovary (Nagle C.M. etal2003).

- Trigonellafoenum-graecum: 
Trigonellafoenum-graecum (Linn.) belonging to family Papilionaceae possess different activities such as anticancer, anti-inflammatory, antiseptic, aphrodisiac, astringent, Bitter, demulcent, emollient, expectorant, anthelmintic, wound healing and gastroprotective. It is also useful in chronic cough, cure leprosy and heart disease and prevent the hair falling off and diuretic. (Toppo F.F. etal2009). This is antidiabeticherb can lower blood glucose and cholesterol levels (Dangi R.S. etal2004).

- Abelmoschus esculentus

The extract from Okra, Abelmoschus esculentus belonging to family Malvaceae, contains (RIPs) ribosome-inactivating proteins recently RIPs have attracted attention because of their pharmacological activities and clinical applications as immunotoxins,Abortifacients and antiviral agents. The study reports for the first time that RIPs exist in Malvaceae plants. (Kondo \&T.yoshikawa2006). The mucilage extracted from Okra was found to be superior disintegrating agentand is devoid of toxicity. (Kumar R. etal2009). The mucilaginous decoction is prescribed for cough, throat infection and bronchitis (Ahmad M. etal2007).

\section{- Solanummelongena}

Egg plant,Solanummelongena is used for the treatment of several diseases including diabetes, arthritis, asthma and bronchitis. (MagioliC. andE. Mansur 2005). S. melongenapossess hypolipidemicpotentials and may therefore be useful for prophylonicand therapeutic treatment of clinical conditions associated with hyperlipidaemiasuch as atherosclerosis. (OdetolaA.Aetal2004). The beneficial actions of flavonoidsfrom egg plantor brinjal provide a higher rate of degradation of cholesterol.

\section{- Momordicacharantia}

M. charantia Fruit extracthas antioxidant, and chemoprotectiveeffects which exert a beneficial action against pathophysiologicalalteration caused by the presence of super oxide and hydroxide radicals. (SEMIZA \& A. SEN.2007). Juice from Momordicacharantia fruit is used for diabetes. Momordicacharantiahavethe medicinal properties such as tonic, purgative, anthelmintic, laxative, sedative, expectorant, and stimulant and is used in the treatment of bronchitis, cough, elephantiasis, piles and ulcers. (Parekh J. andChanda S. 2007).

\section{- Lycopersiconesculentum}

Tomato,Lycopersiconesculentum belonging to family Solanaceae is a source of antioxidants and is made up by components (e.g. Lycopene, Glation, Vitamin C, Vitamin A, Potassium and Calcium) very appropriate for detoxification, illness, prevention, attaining growth, helping the immunologic system, maintaining bloodin good state. Lycopenehas anti-cancerous properties. (Emmanuel Q.C. etal2009). Fresh juice of ripedfruit is used to reduce the acidity of the stomach and to treat inflammation of oesophagusand stomach. (HayatM.Q. etal2008).

\section{- Allium cepa}

Onion, belonging to family Liliaceaein its raw form, is recognized as an antiplaterletagent that may contribute to the prevention of cardiovascular diseases (Cavagnaro P.E. etal2007). Onion bulbs are used to treat cholera. (HayatM.Q. etal2008). The infusions of onion leave or roots tuber cure the snakebite (Owuor B.Q. andD.P. Kisangau2006).

\section{- Momordica tuberosea}

M. tuberosea (Athalakkai) belonging to the family Cucurbitaceae, is Rich in crude fiber, Calcium, Potassium, sodium and Vitamin C. Calcium is required for the growth of bones and teeth as well as for maintaining normal heart rhythm, blood coagulation, muscle contraction and nerve responses. The higher crude fiber content of Athalakkai (2.75 times) Decrease the absorption of cholesterol from the gut. Non vegetarians can potentially include this crude fiber rich wild vegetable in their diet to decrease many gastrointestinal disorders. It is also useful for diabetes (Parvathi S. andV.J.F. Kumar 2002).

\section{- Colocasiaesculenta}

Taro (Colocasiaesculenta L.) a root crop belonging to the Araceae family, is used in treating certain medical conditions, especially infant food allergies and failure-to thrive in infants, diarrhea, gastroenteritis, irritable bowel syndrome and inflammatory bowel disease, cancer, depressed immune function and inadequate lactose digestion. It might make a nutrition supplement for weight gain in patients with conditions such as cancer AIDS, Pancreatitis and some of the induced weight loss conditions of the gastrointestinal tract such as inflammatory bowel disease. (Brown A.C. andA. valiere2004). Its cormis used as an abortifacient, to treat tuberculosis, anathementic, ulcers and pulmonary congestion. (BelozA.G and T. Rivero 2006).

\section{- Ipomoeabatatas}

Sweet purple potato (Ipomoeabatatas) has been regarded as an abundant source of stable Anthocyanins which have been reported to show several effectivelypharmacological properties such as anti-inflammation, antioxidationand antimutagen. Purple sweet potato color is one of the major flavonoidswhich have powerful antioxidants. (Shan Q. etal2007). Sweet potato leaves contain high concentrations of polyphenolics, that offers protection from diseases linked to oxidation, such as cancer, hepatotoxicity, allergies, aging, human immunodeficiency virus and cardiovascular problems. (Islam S. 2006).

- Beta vulgaris

Beta vulgaris has aphrodiasic, carminative, diuretic, expectorant, purgative and toxic properties against itch, constipation earache, headache, inflammations, sores, paralysis and ulcers. (Parekh J. andChanda S. 2007). 


\section{- Spinasiaoleraceae}

Spinach is known as to be healthy productand contains relatively high concentrations of bioactive compounds (ascorbic acid, flavonoids, and carotenoids) and has been correlated to a decreased risk of most degenerative diseases of ageing such as cardiovascular disease, cataracts, and several forms of cancers. (Bergquist S. 2006). Spinach leaves are rich antioxidants like carotenoids ( $\beta$-carotene, lutein and zeaxanthin) and high content of proteins, minerals, and vitamin $\mathrm{C}$; Spinach has protective effect against radiation induced oxidative stress. (SisodiaR. etal2008). Spinach leaves are studied in order to explore the full potential of this plant in human radiation protection and it has anti proliferative activities against human liver cancer cells. (Bhatia A.L and M. Jain 2004). The fresh leaves of Spinach are used to treat anemia (Hayat M.Q. etal2008).Spinasiaoleraceaeis carminative, diuretic, and expectorant, purgative and used in the treatment of constipation earache, headache, sores, inflammations, paralysis and ulcers. (Parekh J. andChanda S. 2007).

- Phaseolus vulgaris

Rajmah(Phaseolus vulgaris) reduce the postprandial plasma glucose levels and contain viscous fibers which are more suited for the diet of diabetic.(DilawariJ.B. etal1981).Phaseolus vulgaris extractproduced significant decrease the body fat while essentially maintaining lean body mass. (CellenoL. etal2007).

\section{- Daucuscarota}

Dietry carotenoids rich extracts from Carrots, tomatoes and orange juices have been thought to play a role in early stages of hepatocarcinogenesis. Extracts of Daucuscarota show antioxidant activity which help in cancer prevention.Carrotsroots and juice are used for treating weak eyesight. (HayatM.Q. etal2008).Daucuscarota (Gajar) is used for improving eyesight and blood purification. (Kala C.P. 2005). Carrot also helps to reduce the risk of squamous cell carcinoma of the oesophagus. (Stefani E.D. 2005).

\section{- $\quad$ Brassica rapa}

Turnip (Brassica rapa) is used to treat stomachache, high blood pressure and diabetes. (Kala C.P., 2005). The semi hot decoction and boiled turnips rubbed on feet to treat cracked skin on feet. (HayatM.Q. etal2008).

\section{- Raphanussativus}

Raphanussativus belongs to family Cruciferae, the juice obtained from the underground part of the plant is cooked with sesame oil (Til) until all the juice is mixed and oil is left behind; this oil is then used as ear drops for the treatment of ear ailments. (Ahmad M. etal2007).its use in the morning before break fastis goodto treat jaundice and its juice is applied on head to treat baldness (Hayat M.Q. etal2008).

\section{- Brassica oleraceae}

Brassica oleraceae belongs to family Brassicaceae; the consumption of cabbage in the food has a protective effect against the carcinoma of the oesophagus. (Stefani E.D. 2005). The risk of RCC (Renal Cell Carcinoma) has been decreased with the increased consumption of white cabbage (Rashidkhani B. etal2005).

- Cucumissativus

The fruit of Cucumissativusis used to treat inflammation. (HayatM.Q. etal2008).

- $\quad$ Cucumismelo

Kakri(Cucumismelo) commonly knew as snap melon. The mature fruits of Cucumismeloexert cooling effect, improve appetite, and cure stomach pain, vomiting and constipation. (Goyal M. andSK. Sharma 2008).

\section{- Cucumiscallosus}

themature fruits of Kachri, a drought tolerant cucurbitaceousvegetable exertcooling effect, improve appetite, relieves stomach pain, vomiting and constipation. (Goyal M. andSK. Sharma 2008).

- Ocimumgratissimum:(Leafy vegetable)

Ocimumgratissimum contains alkaloids, saponins, tannins, phlobatannins,anthraquinones, steroids, terpenoids, flavonoids and cardiac glycosides and is used for treating miscarriages due to its mode of action of flavonoidsthrough their ability to prevent platelet aggregation (thinning of blood). (Ogbe.F.M.D. etal2009).

- $\quad$ Telfairia occidentalis

T. occidentaliscontains micro and macro elements (e.g. $\mathrm{P}, \mathrm{Mg}, \mathrm{Fe}, \& \mathrm{Zn}$ ), cyanide, tannins, oxalate\&phytates\&is used in treating anemia in pregnant women. (Ogbe.F.M.D. etal2009).

- Allium sativum

Garlic has beneficial effects on the cardiovascular and immune system due to its antibacterial, antiviral, antifungal and antiptotozoalactivity. (Harris J.C. etal2001).

Many epidemiological studies support the protective role of garlic and related alliumsfoods against the development of certain human cancers including those of gastro- intestinal tract and prostratecancer. (El-Bayoumy K. etal2006).

- Solanumtuberosum

S. tuberosumbelongs to familySolanaceae and helps to reduce the risk of squamous cell carcinoma of the oesophagus. (Stefani E.D. 2005). 


\section{Recommendations}

Eating 5 vegetables a day prevent nutritional deficiencies and treat diseases such as cancer, heart disease, diabetes and obesity.

Results of past/present research on vegetables should be made available to the local population; especially those with special nutritional and medicinal values rather than locking them in scientific laboratory for use by pharmaceutical and multinational companies or just for academic purposes. This way the indigenous population would be aware of the importance of these vegetables in their vicinity and thus, the need to consume and preserve them.

\section{References}

[1] Afzal M., M. Ali., M. Thomson and D. Armstrong .2000.Garlic and its medicinal potential. Inflammopharmacology.8 (2):123-148.2000.

[2] Ahmad,M., M.A. Khan., M. Zafar and S. Sultana.2007. Treatment of common ailments by plant based remedies among the people of district Attock (Punjab) of northern Pakistan. Afr. J.T rad. CAM.4 (1): 112-120.2007.

[3] Aroidof the Warao.A journal of plant people and applied research.4:103-

[4] Athar,M. andS.M. Nasir .2005. Taxonomic perspectiveof plant species yielding vegetable oil used in cosmetics and skin care products. African journal of biotechnology.4:36-44. 2005.

[5] Beloz,A.G. andT. Rivero .2006. Ure(ColocasiaesculentaAraceae): An edible

[6] Bergquist,S. 2006. Bioactive compounds in baby Spinach (Spinaciaoleraceae L.): effects of pre- and post harvest factors. Doctoral dissertation. 2006.

[7] Bhatia A. L. andM. Jain 2003.Spinaciaoleraceae L. protectsagainst gamma radiation: a study on glutathioneand lipid per oxidation in mouse liver. Phymedicine.11:607-615.2003.

[8] Brown,A.C. andA. Valiene.2004. The medicinal uses of Poi.Nutr.Clin.Care. 7 (2):69-74.2004.

[9] Cavagnaro,P.F., M.M. Sanceand C.R. Galmarini.2007. Effectof heating on onion (Allium cepa L.) antiplaterletactivity and pungency sensory perception.Food.Sci. Tech. Int. 13(6):447-453.2007.

[10] Celleno,L., M.V. Tolaini., A.D. Amore., N.V. Perricone and H.G. Preuss.2007. A dietary supplement containing standardized Phaseolus vulgaris extract influences body composition of over weightmen and women. Int. J.Med.Sci.4:45-52.2007.

[11] Dangi,R.S., M.D. Lagu., L.B. Choudhary., P.K. Ranjekarand V.S. Gupta .2004. Assessment of genetic diversity in Trigonellafoenum-graecum and Trigonellacaerulea using ISSR and RAPD markers. National botanical research.4:2004.

[12] Dilawari,J.B., P.S. Kamath., R.P. Batta., S. Mukewarand S. Raghavan 1981. Reduction of postprandial plasma glucose by Bengal gram dal (Cicerarietinum) and Rajmah (Phaseolus vulgaris). Am. J. Clin. Nutr.34:2450-2453.1981.

[13] Doorn.M.B.A., S. M. E. Santo., P. Meijer., I. M. Kamerling., R. C. Schoemaker., V. Dirsch., A. Vollmar., T. Haffner., R. Gebhardt., A.F. Cohen., H.M. Princenand J. Burggraaf.2006. Effect of garlic powder on C-reative protein and plasma lipids in over weight and smoking subjects. American journal of clinical nutrition.84 (6):1324-1329.2006.

[14] El-Bayoumy,K., R. Sinha, J. T. Pinto and R. S. Rivlin 2006. Cancer chemoprevention by garlic and garlic-containing sulfur and selenium compounds. J. Nutr. 136:864-869.2006.

[15] Emmanuel,S. O., A. AdeoluA., O. OyebowaleO. A., Ebenezer A., I. Olufunto., A. Ayobami. andA. Taiwo.2009. Prevention pfrenal toxicity from lead exposure by oral administration of Lycopersiconesculentum.Journal of toxicology an environmental health sciences. 1(2):022027.2009 .

[16] Ghayur,M.N. andA.H. Gillani.2005. Pharmacological basis for the medicinal use of ginger in gastrointestinal disorders. Digestive diseases and sciences.50:1889-1897.2005.

[17] Goodrich,W. S. andRosati .2008. Nutraceuticalfor the prevention and treatment of cancers and diseases affecting the liver.2008.

[18] Goyal M. andS.K. Sharma .2009.Traditional wisdom and value addition prospects of arid foods of desert region of North West India. Indian journal of traditional knowledge .8(4):581-585.2009.

[19] Harris,J.C., S. L. Cotterel., S. Plummer and D. Lloyd.2001. Antimicrobial activities of Allium sativum (garlic).Appl. Microbial biotechnol.57:282-286.2001.

[20] HayatM. Q., M. A. Khan., M. Ahmad., N. Shaheen., G. Yasmin and S. Akhter.2008.Ethnotaxonomical approach in the identification of useful medicinal flora Tehsil pindigheb(District Attock) Pakistan.Ethnobotany research and application.6:035-062.2008.

[21] Islam,S.2006.Sweetpotato (Ipomoea batatas L.) Leaf: Its potential effect on human health and nutrition.Journal of food sciences.71:2006.

[22] Kala,C. P.2005. Current status of medicinal plants used by traditional vaidyasin Uttaranchal state of India. Ethnobotany research and applications.3:267-278.2005.

[23] Keiss,H. P., V. M. Dirch., T. Hartung., T.Haffner., L. Trueman., J. Auger., R. Kahane and A. M. Vollmar.2003.Garlic (Allium sativum) modulates cytokine expression in lipopolysaccharide-activated human blood thereby inhibiting NF-KB activity. The American society for nutritional sciences J. Nutr.133:2171-2175.2003.111.2006.

[24] Kimiywe,J., J. Waudo., D. Mbitheand P. Maundu.2007. Utilization of medicinal value of indigenousleafy vegetables consumed in urban and peri-urban Nairobi. Aferican journal of food agriculture nutrition and development. 4:16-19.2007.

[25] Kondo,T. andT. Yoshikawa .2007. Purification and characterization of Abelesculin, a novel ribosome-inactivating protein from the mature seeds of Abelmoschusesculentus. J. Nat. Med. 61:172-174.2007.

[26] Kumar,R., M. B. Patil., S. R. Patil., and M.S. Paschapur.2009.Evaluation of disintegrating properties of Abelmoschusesculentus mucilage. International journal of pharm Tech research.1 (2):241-246.2009.

[27] Liu,S., J.E. Manson., I-M. Lee., S. R. Cole., C. H. Hennekens., W. C. Willett and J. E. Buring. 2000. Fruit and vegetable intake and risk of cardiovascular disease. The women's health study, The American journal of clinical nutrition.72:922-928.2000.

[28] Magioli,C. and E. Mansur .2005. Eggplant (Solanummelongena L.): tissue culture, genetic transformation and use as an alternatives model plant. Acta. Bot. Bras.19 (1:2005).

[29] Mathieu,G. and D. Meissa .2007. Traditional leafy vegetables in Senegal: Diversity and medicinal uses. Afr. J. Trad. CAM.4 (4):469475.2007.

[30] Nagle,C. M., D. M. Purdie., P. M. Webb., A. Green., P. W. Harvey and C. J Bain .2003. Dietry influences on survival after ovarian cancer. Int. J. Cancer. 106:264-269.2003. 
[31] Odetola,A., A Y. O. Iranloye and O. Akinloye .2004. Hypolipidaemic potentials of Solanummelongena and Solanumgilo on hypercholesterolemic rabbits. Pak. journal of nutrition 3(3):180-187.2004.

[32] Ogbe,F. M. D., O. L. Eruogenand M. Uwagboe.2009. Plants used for female reproductive health care in Oredo local government area. Nigeria. Scientific research and essay. 4(3): 120-130.2009.

[33] Owuor,B.O. andD. P. Kisangau.2006. Kenyan medicinal plants used as anti venin: a comparison of plant usage. Journal of ethnobiology and ethnomedicine. 2(7):2006.

[34] Parekh,J. andS. Chanda.2007. In vitro screening of antibacterial activity of aqueous and alcoholic extracts of various Indian plant species against selected pathogens from enterobacteriaceae.Afr. J. Mic.Bio. Rea.1 (6):092-099.2007.

[35] Parvathi, S. andV. J. F. Kumar .2002.Studies on chemical composition and utilization of the wild edible vegetable athalakkai(Momordicatuberosa).Plant foods for human nutrition.57: 215-222.2002.

[36] Rashidkhani,B., P.Lindblad and A. Wolk.2005. Fruits, Vegetables and risk of renal cell carcinoma: A prospective study of Swedish women.Int. J. Cancer. 113: 451-455.2005.

[37] SEMIZ A. andA. SEN .2007. Antioxidant and chemoprotective properties of Momordicacharantia L. (bittermelon) fruit extract. African journal of biotechnology.6(3):273.277.2007.

[38] Shan,Q., Y. Zheng., J. Li., Z. Zhou., B. Hu., Z. Zhang., S. Fan., Z. Mao., Y. J. Wang and D. Ma. 2009. Purple sweet potato color ameliorates cognition deficits and attenuates oxidative damage and inflammation in aging mouse brain induced by D-galactose. Journal of biomedicine and biotechnology.1: pgs9.2009.

[39] Sidhu,K., J. Kaur., G. Kaur and K. Pannu.2007. Prevention and cure of digestive disorders through the use of medicinal plants. J. Hum. Ecol. 21(2):113-116.2007.

[40] Sisodia,R., R. K. Yadar., K. V. Sharma and A. L. Bhatia.2009. Spinaciaoleraceae modulates radiation-induced biochemical changes in micetestis. The journal search current issue archives instructions login.70 (3):320-326.2009.

[41] Stefani,E. D., P. Boffetta, H. D. Pellegrini, A. L. Ronco, P. Correa and M. Mendilaharusu.2005. The role of vegetable and fruit consumption in the aetiologyof squamous cell carcinoma of the oesophagus: a case-control study in Uruguay.Int. J. Cancer.116:130-135.2005.

[42] Toppo,F.A., R. Akhandand A. K. Pathak 2009. Pharmacological actions and potential use of TrigonellaFoenum-Graecum: a review.Asian journal of Pharmaceutical and clinical research.2 (4):29-38.2009. 